\title{
The Preconditions for Producer Power: the OPEC Example
}

\section{Hanns Maull}

The emergence of the Organization of Petroleum Exporting Countries as a powerful actor on the world scene has fundamentally changed not only the international oil market, but also the very character of international relations. Yet the power of OPEC-demonstrated in the development of oil prices as well as in the application of supply reductions as a political weapon by a group of Arab oil producers-has not only shown its capabilities, but also its limitations. The real value of oil has already been eroded considerably since 1974, and the oil weapon (though no doubt an important ever in international relations) was sheathed long before its declared objectives had been reached. Besides, OPEC's power became obvious only after ten years of the organization's existence.

It was the year 1970 which constituted a watershed in the international oil market - and it was Libya which played a crucial role in this development. Libya was the first to demonstrate the freedom of manoeuvre of the producers by forcing the companies operating in the country to reduce output, and then to accept higher prices and changes in the tax structure. A variety of particular circumstances at that time helped Libya in succeeding with its confrontation tactics, but these circumstances only exacerbated the underlying changes in the international oil market. The relationship of forces between producers and consumers had changed fundamentally.

The basis of OPEC's power lies in the trade relationship between oil exporting and industrialised oil consuming countries; it consists essentially in the ability to withhold supplies. A measure of this power is the amount of damage the reduction or interruption of supplies would cause in the consumer countries. The first ingredient of OPEC oil power is therefore the high dependence of consumers on continued and sufficient supplies.

To illustrate this point, it is sufficient to recall the overriding importance of energy in the functioning of a modern society. The correlation between energy consumption and economic growth is a close one. During the supply crisis $1973 / 74$, the Japanese government estimated that a 16 per cent shortfall in oil supplies (oil imports accounted for about 85 per cent of total energy requirements) would imply a 10 per cent decline in National Income, and falls of production of 20 per cent in the chemical industries, 15 per cent in the automobile industries, and 11-15 per cent in steel. While Japan's dependence on oil imports to cover total energy requirements was the most pronounced of the main industrialised countries, other areas were also heavily dependent (Western Europe to about 63 per cent, the United States to about 17.5 per cent).

High dependence, however, meant in fact more than this. It also implied that any shortfall of oil imports from the oil producer action group (be it OPEC which used the threat of supply interruptions as bargaining card, or Arab producers who unsheathed the oil weapon) could not be replaced. Replacement, in turn, could mean two things: diversification or substitution.

A first factor barring replacement is simply the enormous quantities involved in the international trade in oil. Total OPEC oil exports in 1973 amounted to $1,311.777$ mill.t. Maximum reductions in output of the Arab oil producers during the $1973 / 74$ crisis stood at about 4.2 mill.b/d (approx. 210 mill.t/year). These considerable quantities have to be contrasted with the fact that there has been virtually no stand-by capacity to increase oil production substantially outside OPEC since US production peaked out in 1970; and even within OPEC stand-by capacity is heavily concentrated in the Arab world. Stocks could also not fill the gap, since the nature of oil makes stocking of large amounts expensive. (However, expanded stock programmes in the industrialised countries have been put into effect in recent years, resulting in a reduction of vulnerability.)

So diversification was--and is--no solution for the reduction of dependence of industrialised consumer countries. Neither is substitution of oil by other sources of energy-mainly again because of the enormous amounts involved, but also because of the difficulty of increasing production in alternative sources of energy such as coal, natural gas and nuclear energy.

Finally, recycling of oil again did not offer any prospects of reducing dependence (contrary to other raw materials such as copper or iron): oil is mainly burned to provide energy, and only the small share of consumption by the industries which use oil as a raw material can in principle be recycled.

The second factor accounting for oil power is the uneven distribution of losses between producers 
and consumers in the case of supply reductions. While we already have seen that the overriding importance of energy makes consumers extremely vulnerable, the producers as a group would suffer much less from a reduction of production. In fact, even now production rates of OPEC as a group are higher than necessary to earn the revenues required domestically, and it can be argued that some producers still export much more oil than is in their economic interest. This has led to the accumulation of huge financial surpluses-and these surpluses contribute to making producers better equipped to face confrontation in the international oil market. Theoretically, some producers could virtually stop production and exports, and pay their import bills out of their reserves for a considerable length of time. However, this did not even prove necessary in 1973/74 since the low elasticity of demand in the short term made it possible to increase prices by more than the amount necessary to make up the shortfall in revenues as a consequence of export reductions.

Even the danger of longer-term effects of increased prices did not really constitute a weakness of the producers (though that was far from clear at the time). The price of oil in relation to alternative sources of energy was until 1973 so low that even the quadrupling of $1973 / 74$ did not make it uncompetitive. Moreover OPEC not only controls a vast share of total world oil reserves, but reserves with a very high competitive margin in terms of investment outlays as well as production costs. The potential to increase prices was, therefore, very huge in 1973.

The only real ceiling to oil power appears to lie in the political and economic interdependence of producers and consumers: a severe crisis in the industrialised countries is bound eventually to affect the economies of the oil producers; it also might have political repercussions which are thought undesirable by producers. In that sense, oil power now appears to have been pushed close to its limitations.

The third ingredient of oil power is the fact that -at least in the short term-consumer dependence on oil is not balanced by producer dependence on trade with the industrialised countries. Various possibilities of organising a counter-embargo against the Arab oil producers were discussed in 1973/74-and rejected as impracticable. However, to the extent that oil producers manage to industrialise they will become more closely integrated into the world economy-and this, no doubt, will reduce their oil power. While oil power in the short term gives considerable leverage on the basis of an imbalanced trade relationship, there is an inverse underlying imbalance - the imbalance between industrialised and developing countries. It still has to be seen whether oil power is sufficient to redress this imbalance before it is eroded.

Fourthly, oil power was made possible only through a substantial change in the international system itself. The Western world has gradually lost control over producer countries - a control which rested on the direct political influence and military power of the West, and the power of the oil companies, particularly the majors. The erosion of control became obvious in 1973/74the American threat of military intervention was at best the threat of totally irrational behaviour should the supply crisis become unbearable; it did not constitute a viable political option to preserve Western interests. The change in the international system can probably be interpreted as a weakening of feudal elements in its structure. The international system was 'feudal' in the sense that it rested on interaction between the centre states (the industrialised countries) and between centre states and periphery states (the developing countries) in bilateral relations, while interaction between periphery states was almost nonexistent. It was the co-operation between OPEC states, and within the Arab producer action group, which contributed to the successes of oil power. Even this co-operation, however, has shown its limitations in the inability to agree on a formal production prorationing scheme, and in the marginal competition between producers in recent months. All of which would lead one to conclude that the degree of co-operation (and willingness to subordinate immediate interests for long-term gain) which would be required of other raw material producers in order to emulate the success of OPEC would be very great indeed. The special ingredients of OPEC power which have been enumerated above-the high degree of importer dependence, the high cost of stock-piling and limited possibilities of substitution or recycling, the producers' control over cheaply exploitable reserves, their substantial foreign exchange reserves and low dependence on imports-are likely to be absent, or present in a much weaker form, in the case of other commodities. Additional strength might be gained if co-operative action were to embrace the producers of several commodities, rather than of a single commodity. But the basic power imbalance between the developed and the developing countries probably makes the co-operation of the former essential for any attempt to renovate the international economic order. In the long run commodity agreements will probably prove a more profitable solution to the developing countries than producer cartels-for oil as well as for other commodities. 